\title{
The Impact of Board and Audit Characteristics on the Financial Performance of UAE Listed Firms
}

\author{
Abdulfattah Mohamed G Khalifa H (Corresponding author) \\ Victoria University Business School, Victoria University, Melbourne, Australia \\ Department of Management, Business School, Tripoli University, Tripoli, Libya \\ E-mail: abdulfattah.khalifah@live.vu.edu.au or Abdu_4244@yahoo.com \\ Riccardo Natoli \\ Victoria University Business School, Victoria University, Melbourne, Australia
}

Segu Zuhair

Department of Business, Management and Finance, Melbourne Polytechnic, Australia

Received: February 18, 2020

Accepted: April 17, 2020

Published: June 30, 2020

doi:10.5296/ijafr.v10i2.16481

URL: https://doi.org/10.5296/ijafr.v10i2.16481

\begin{abstract}
Purpose - The purpose of this paper is to provide empirical insights on the impact of board and audit committee characteristics on the financial performance of United Arab Emirates (UAE) listed firms.

Design/methodology/approach - A multiple regression panel model was employed for the period 2006 to 2015. The analysis incorporates Anderson Lagrange Multiplier test and Hausman test to determine if a fixed effects or random effects model should be employed.

Findings - Our results demonstrated that board size and board meetings had a significant positive relationship with financial performance while there were also significant positive relationships between both audit committee composition and audit committee members' education and firm financial performance.

Research limitations/implications - The findings inform UAE firms about the benefits of employing directors with a more diverse skill set to enhance board effectiveness as well as
\end{abstract}


having audit committee members hold a recognised qualification in finance or accounting to improve firm financial performance.

Originality/value - Our study contributes to the CG literature by adding to the limited studies on CG in the UAE which help reduce the significant gap between foundation theories and practical applicability.

Keywords: Board characteristics, Audit characteristics, Firm performance, UAE

\section{Introduction}

In this paper, we investigate the association between board and audit committee characteristics and the financial performance of United Arab Emirates (UAE) firms. Our motivation for investigating the issue arises from the fact that despite the rapid growth and high levels of foreign investment experienced in the UAE which, from a per capita perspective, has the UAE among the top 30 economies in the world (Trading Economics, 2017), the regulatory and legal framework in the UAE has, as yet, failed to keep up with these changes. Consequently, a disparity exists between the two. According to Andrew (2015), this has led to an absence of financial disclosure laws, which renders implementation of corporate governance (CG) policies ineffective.

Such CG policies refer initially to the first voluntary CG code established by the UAE government via Decision No. R/32 of 2007. This presented the primary regulatory framework for the Emirates Securities and Commodities Authority (ESCA). In 2010, the second CG code became mandatory for all listed companies via Ministerial Resolution No. 518 of 2009, with these companies required to comply with the code by 30 April 2010. The shift to a more transparent and regulated financial environment via the implementation of CG codes with is focus on roles and responsibilities of board directors, auditors and other stakeholders (ESCA, 2016) has had direct effects on board and audit committee characteristics (Steven and Carla 2010).

While studies in developed countries on the effect of CG on corporate financial performance report evidence that some corporate governance mechanisms have a crucial impact, that there is still a paucity of studies in the UAE (and developing countries in general), particularly in the area of audit committee characteristics. Subsequently, the relationship between CG and financial performance is not as well understood in developing countries as it is in the developed world (Elghuweel, 2015). Generalisation of the findings of the few studies that have examined $\mathrm{CG}$ in specific Middle Eastern countries are invalid, as posited by Ananchotikul (2007), because of the variations in the regulatory regimes. This limited understanding of the $\mathrm{CG}$ mechanisms and their impact on corporate performance among Middle Eastern countries enhances the importance of a UAE specific study examining the effect of CG characteristics on firm financial performance.

Consequently, the main objective of this study is to identify the relationship between board and audit committee characteristics on the financial performance of UAE listed firms. The study employs data on 47 listed companies on the Dubai Financial Market (DFM) and Abu 


\section{Mll Macrothink}

International Journal of Accounting and Financial Reporting

ISSN 2162-3082

2020, Vol. 10, No. 2

Dhabi Securities Exchange (ADX), covering the period 2006 to 2015. The data were analysed via a multiple regression panel model.

Our empirical results show that board size and board meetings had a significant positive relationship with financial performance (as measured by return on assets [ROA] and return on equity [ROE]).Significant positive relationships was found to exist between financial performance and audit committee composition, audit committee members' education and the number of audit committee meetings.

Our study contributes to the CG literature by adding to the limited studies on CG in the UAE which help reduce the significant gap between foundation theories and practical applicability. The remainder of this paper is organised as follows. Section 2 reviews prior empirical literature and develops the hypothesis. Section 3 describes the research design. Section 4 presents results and discusses findings. Section 5 draws conclusions, presents the implications and discusses recommendations for further research.

\section{Literature Review and Hypothesis Development}

\subsection{Multi-Theoretic Approach}

This study framework combines agency theory and resource dependence theory to develop and understanding of the complex nature of CG. For instance, agency theory states that independent directors provide important monitoring functions in an attempt to resolve the conflict between agents and principals - an aspect ignored by stewardship theory. Agency theory also provides the basis for the governance standards, codes and principles developed by the Organisation for Economic Co-operation and Development (OECD) (OECD, 2004, 2015). More importantly, the 2009 UAE CG code, which constitutes a cornerstone of the UAE CG reforms, aims to reduce conflicts between managers and shareholders by improving the transparency, accountability and responsibility of corporate boards of directors.

In addition, the economy of the Gulf States has been reliant on international workforce for a prolonged period. This characteristic is best reflected by resource dependence theory because it provides a comprehensive exposition of the relationship between a firm and its external environment and resources (Pfeffer and Salancik 2003).

\subsection{Board and Audit Committee Characteristics}

According to Boone et al. (2007), the board holds a very significant place in the design of a corporate organisation and stands accountable to stakeholders. Active and successful boards of directors monitor management to reduce managerial activities unaligned with shareholder interests. On the role of audit committees, Almatari, Alswidi and Fadzil (2014a) state that audit committee members have a potential to make a significant contribution to minimising financial fraud and improving financial performance by ensuring that CG practices are followed in the auditing process. Given this established positive effect of board and audit characteristics on firm financial performance, the following sub-sections provides a succinct review of empirical studies, with a greater emphasis on developing country studies, that focus 
on the impact of board and audit characteristics on a firm's financial performance as measured by ROA and ROE.

\subsection{Board Size}

In theory, firms should benefit from having larger boards for monitoring, strategy formulation and access to resources leading to improved financial performance. Empirical studies by Almatari et al. (2014b) and Johl et al. (2015) demonstrated a significant positive relationship between board size and firm financial performance in Oman and Malaysia respectively. Other studies such as Rouf (2011) in Banagladesh and Ghabayen (2012) in the Kingdom of Saudi Arabia (KSA) did not identify any significant relationship. Kajola (2008) found a significant positive relationship. Based on the overall findings, the following hypothesis is developed:

H1: There is a positive relationship between board size and firm financial performance in the UAE.

\subsection{Board Independent Directors}

As Dalton et al. (1998) found, firms with a majority of independent directors on the board enhances its effectiveness and provides superior performance. According to studies by Yasser et al. (2011) and later by Khan and Awan (2012) on Pakistan data and Kyereboah-Coleman and Biekpe (2006) in Ghana, there was a significant positive relationship between independent directors and firm financial performance as measured by a combination of ROA and ROE. Conversely, Ghabayen's (2012) study in KSA identified a significant negative relationship while studies on Nigeria from both Dabor et al. (2015) and Kajola (2008) did not identify any significant relationships. Based on the overall findings, the following hypothesis is developed:

$\mathrm{H} 2$ : There is a positive relationship between board independent directors and firm financial performance in the UAE.

\subsection{Board Meetings}

Several studies have confirmed that board meetings-as measured by the number of meetings per annum-play an important role in the governance, regulatory compliance and performance of companies (Jensen, 1993; Lipton and Lorsch, 1992). With respect to the empirical findings, there were some mixed results arising from examining the relationship between board meetings and firm financial performance. For example, Ntim and Oseit's (2011) South African study showed a significant positive relationship as too did Hsu and Petchsakulwong's (2010) Thailand study. However, Johl et al.'s (2015) Malaysian study exhibited a significant negative relationship. This led to the following hypothesis:

H3: There is a positive relationship between board meetings and firm financial performance in the UAE.

\subsection{Board Members' Education}

According to Almatari et al. (2013), having a qualified and educated member on the board improves firm financial performance. A number of studies have identified a significant 
positive relationship between board members' education and firm financial performance (Almatari et al., 2013; Gottesman and Morey, 2006; Vo and Phan, 2013; Hsu, 2010). Consequently, the hypothesis for this study is:

H4: There is a positive relationship between board members' education and firm financial performance in the UAE.

\subsection{Board Members' Experience}

According to Pfeffer and Salancik (2003), board members with greater experience bring with them skills, knowledge and expertise which can positively affect firms' financial performance. This is supported by the findings of Vo and Phan (2013) in Vietnam, Hsu (2010) Zhu and Shen (2016) in USA, Johl et al. (2015) in Malaysia, and Mura (2007) in the UK, where all exhibited strong significant positive relationships between board members' experience and firm financial performance. Based on the overall findings, the following hypothesis is developed:

H5: There is a positive relationship between board members' experience and firm financial performance in the UAE.

\subsection{Audit Committee Size}

In theory, firms with a larger audit committee size should benefit financially compared to firms with a smaller audit committee size (Khalifa, 2018). Empirical studies by Hamdan et al. (2013), Aldamen et al. (2012), Kyereboah-Coleman (2008) and Ibrahim et al. (2009) established a significant positive relationship between audit committee size and firm financial performance. Conversely, studies from Almatari et al. (2012) and Vafeas (1999) have showed a significant negative relationship. Furthermore, studies by Ghabayen (2012) as well as Mak and Kusnadi (2005) did not identify any significant relationship. Based on the overall findings, the following hypothesis is developed:

H6: There is a positive relationship between audit committee size and firm financial performance in the UAE.

\subsection{Audit Committee Independent Members}

According to Khalifa (2018), independent members of the audit committee play an important role in improving the monitoring of management which can lead to improved firm financial performance. Empirical studies by Yasser et al. (2011) and Almatari et al. (2014b) in Pakistan and Oman respectively showed that there was a significant positive relationship between independent members of the audit committee and firm financial performance. However, empirical studies from Ghabayen (2012) and Kajola (2008) in KSA and Nigeria respectively identified no significant relationship. Based on the overall findings, the following hypothesis is developed:

H7: There is a positive relationship between audit committee independent members and firm financial performance in the UAE. 


\subsection{Audit Committee Meetings}

Active audit committee meetings play an important role in the governance, compliance and financial performance of companies. One could argue that firm financial performance should improve as the number of meetings increase. The empirical evidence however is mixed. For instance, a study by Almatari et al. (2014b) in Oman identified a significant positive relationship between audit committee meetings and firm financial performance whereas Aldamen et al.'s (2012) Australian study showed a significant negative relationship. Other studies by Hamdan et al. (2013) and Alqatamin (2018) in Amman and Jordan respectively did not identify any significant relationship. Based on the overall findings, the following hypothesis is developed:

H8: There is a positive relationship between audit committee meetings and firm financial performance in the UAE.

\subsection{Audit Committee Members' Education}

According to Aldamen et al. (2012), audit committee members with a background in finance or accounting contribute positively to firm financial performance. Majority of the studies on the influence of audit committee educational background on firm financial performance, have identified a positive relationship (Aldamen et al., 2012; Almatari et al., 2014a; Hamid and Aziz, 2012). There was however a significant negative association found in Badolato et al.'s (2014) UK study. This leads to the following hypothesis:

H9: There is a positive relationship between audit committee members' education and firm financial performance in the UAE.

\subsection{Firm Financial Performance}

As Khatab et al. (2011) posits, the extant literature on CG and firm financial performance regarding accounting-based measures of financial performance are vast. Of these, Almatari et al. (2014c) found that ROA is the most used accounting-based measure (46\%), followed by ROE (27\%). The present research will employ the two most common accounting-based measures: ROA and ROE (Aldamen et al., 2012; Johl, Kaur and Cooper, 2015; Vo and Phan, 2013; Yasser, Entebang and Mansor, 2011) in order to obtain a more robust representation of firm financial performance. In addition, the study will employ three control variables widely used in CG studies: firm age, leverage, and firm size.

\section{Conceptual Framework and Research Method}

\subsection{Conceptual Framework}

Incorporating findings reported in the literature, and the study research questions, a conceptual framework was developed to encompass the associations between CG characteristics and the firm value of UAE listed firms. The framework serves as the foundation for this study and is presented in Figure 1 below. 


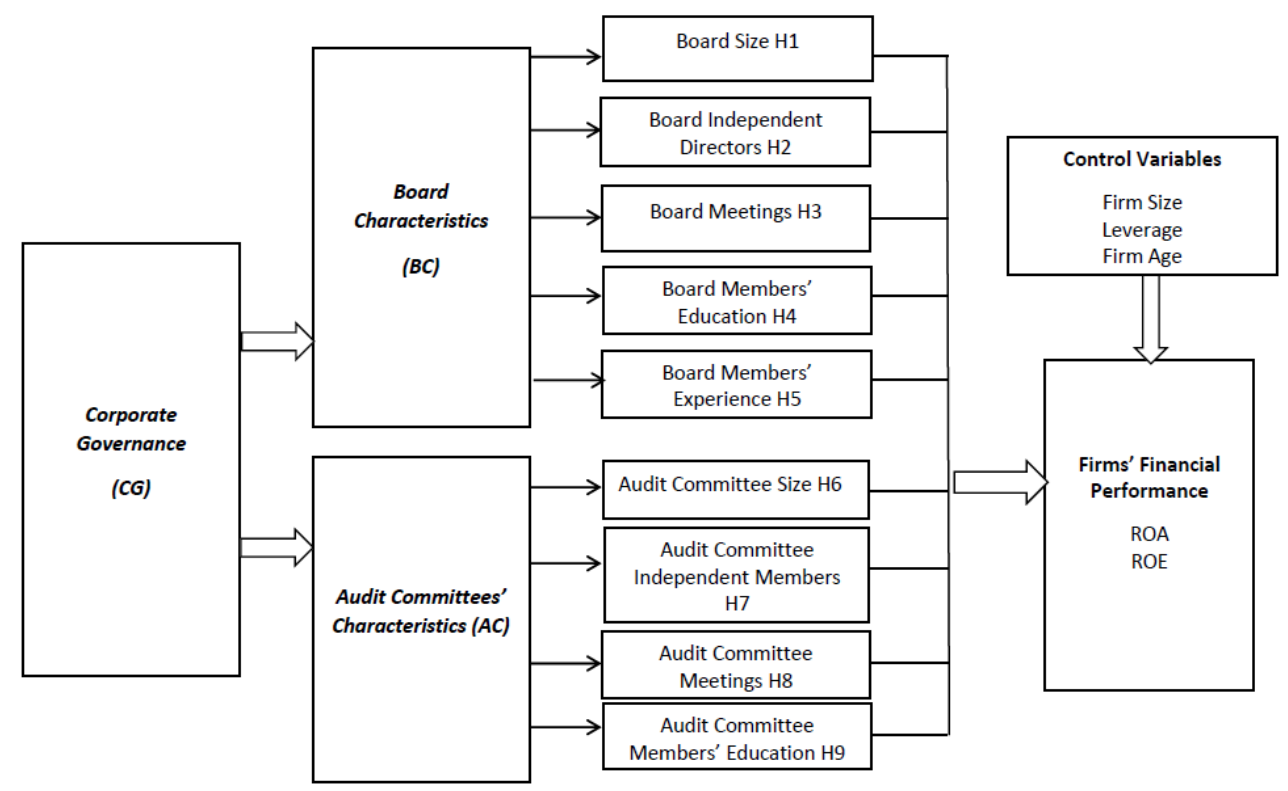

Figure 1. Conceptual framework for the study

\subsection{Data}

This study used secondary data obtained from different online sources: DFM, ADX, Mint Global, Orbis-Bureau van Dijk, DataStream, UAE listed firms' website and ESCA (see Appendix 1 for variable measurement and source). Data related to firm financial performance were obtained from financial statements, such as balance sheets, income statements and cash flow statements provided in annual reports.

The sample initially consisted of all UAE firms listed on the DFM and ADX as of July 2016. The selection of companies was determined by the availability of 10 years of data. In total, there were 127 listed companies at that time, with 59 listed companies on the DFM and 68 listed companies on the ADX for the 10 years from 2006 to 2015. The DFM and ADX markets were chosen because companies on these markets are more likely to attract and employ skilled and competent individuals on the board of directors and audit committees. A purposive sampling technique was used to select companies. The listed companies selected in this study had to meet three criteria: (i) provide information about board and audit committee characteristics for the study period; (ii) provide financial performance information; and (iii) possess complete data for the study period. Based on these criteria, the number of firms was reduced to 61. Another 14 companies were omitted from the study sample because they contained outliers, which is a standard practice (Hair et al., 2010). As a result, the present study's final sample comprised 47 listed firms and 470 total observations.

\subsection{Estimation}

As demonstrated by Baddeley and Barrowclough (2009), ordinary last squares (OLS) is not ideal in the presence of fixed effects (FE), such as firm-specific effects, are time invariant, yet unobservable. If the FE are ignored, especially in a time series data set, heterogeneity bias is generated. The bias occurs because the time-invariant FE that may affect individual 


\section{MIMacrothink}

International Journal of Accounting and Financial Reporting

ISSN 2162-3082 2020, Vol. 10, No. 2

cross-sectional units are not included in the deterministic part of the model. Heterogeneity bias is a form of omitted variable bias that would produce auto-correlated errors. The sample in this study includes data both across firms and over time; thus, panel data regression is the appropriate tool to be applied since it can eliminate heterogeneity bias using either a FE model or a random effects (RE) model (Baddeley and Barrowclough, 2009).

Hence, this study employs panel regression analysis to examine the relationships between the variables selected in the study. Two panel models will be examined-FE and RE-with a Hausman test performed on each. Regression panel data have been employed in previous studies such as those by Kajola (2008) and O'Connell and Cramer (2010), who used them to test the relationship between $\mathrm{CG}$ and firm financial performance.

As stated previously, this paper aims to identify the relationship between board and audit committee characteristics and the financial performance of UAE listed firms. To accomplish this, a multiple regression panel analysis is used to test the aforementioned nine study hypotheses. Two equations are estimated, one for each of the financial performance variables (ROA and ROE). The estimated regression is in the form:

$$
\begin{aligned}
\mathrm{FP}_{\mathrm{it}} & =\alpha+\beta_{1, \mathrm{t}} \mathrm{BS}_{\mathrm{it}}+\beta_{2, \mathrm{t}} \mathrm{BIND}_{\mathrm{it}}+\beta_{3, \mathrm{t}} \mathrm{BM}_{\mathrm{it}}+\beta_{4, \mathrm{t}} \mathrm{BMED}_{\mathrm{it}}+\beta_{5, \mathrm{t}} \mathrm{BMEX}_{\mathrm{it}}+\Sigma \beta_{6, \mathrm{t}} \mathrm{ACS}_{\mathrm{it}} \\
& +\beta_{7, \mathrm{t}} \mathrm{ACIND}_{\mathrm{it}}+\beta_{8, \mathrm{t}} \mathrm{ACM}_{\mathrm{it}}+\beta_{9, \mathrm{t}} \mathrm{ACED}_{\mathrm{it}}+\beta_{10, \mathrm{t}} \mathrm{FA}_{\mathrm{it}}+\beta_{11, \mathrm{t}} \mathrm{LEV}_{\mathrm{it}}+\beta_{12, \mathrm{t}} \mathrm{FS}_{\mathrm{it}}+\mathrm{e}_{\mathrm{it}}
\end{aligned}
$$

where:

$\mathrm{BS}=$ board size

BIND $=$ board independent directors

$\mathrm{BM}=$ board meetings

$\mathrm{BMED}=$ board members' education

$\mathrm{BMEX}=$ board members' experience

ACS $=$ audit committee size

ACIND $=$ audit committee independent members

$\mathrm{ACM}=$ audit committee meetings

ACED $=$ audit committee members' education

$\mathrm{FA}=$ firm age

$\mathrm{LEV}=$ leverage

$\mathrm{FS}=$ firm size

$\mathrm{FP}_{\text {it }}=$ financial performance, ROA or ROE, under company $i$ over time $t$. 


\section{Mll Macrothink}

International Journal of Accounting and Financial Reporting

ISSN 2162-3082

2020, Vol. 10, No. 2

\section{Empirical Results}

\subsection{Descriptive Statistics}

Table 1 below provides the descriptive statistics for the variables related to board and audit characteristics. The mean size of boards in the sample was 7.70, ranging from five to 15 members of which on average, $71.24 \%$, were independent directors. The statistics are in line with the recommendations of the first and second UAE CG codes. The Board met at least once a year with a maximum of 16 meetings per year, and an average of about 6 meetings per year. On average, $74 \%$ of the members had a degree from an overseas university, ranging from $36 \%$ to $100 \%$. On average, board members had 21 years' experience, which ranged 7 to 39 years.

Table 1. Descriptive statistics of board and audit committee characteristics

\begin{tabular}{llllll}
\hline Variable & N & Abbr. & Minimum & Maximum & Mean \\
\hline Board size & 470 & BS & 5 & 15 & 7.70 \\
\hline Board independent directors & 470 & BIND & $33 \%$ & $100 \%$ & $71.24 \%$ \\
\hline Board meetings & 470 & BM & 1 & 16 & 6.15 \\
\hline Board members' education & 470 & BMED & $36 \%$ & $100 \%$ & $74.36 \%$ \\
\hline Board members' experience & 470 & BMEX & 7 & 39 & 21.19 \\
\hline Audit committee size & 470 & ACS & 2 & 7 & 3.32 \\
\hline $\begin{array}{l}\text { Audit committee independent } \\
\text { members }\end{array}$ & 470 & ACIND & $20 \%$ & $100 \%$ & $81.13 \%$ \\
\hline $\begin{array}{l}\text { Audit committee meetings } \\
\text { Audit committee members }\end{array}$ & 470 & ACED & 0 & $100 \%$ & $41.80 \%$ \\
\hline education & & & & & \\
\hline
\end{tabular}

The mean audit committee size in the sample comprised 3.32 committee members, ranging from a minimum of two members to a maximum of seven members. The audit committee size was not stated in the first CG code in the UAE, while the second code stated that the audit committee should have at least three members. In addition, on average, $81.13 \%$ of audit committee members were independent, with a minimum of $20 \%$ and a maximum of $100 \%$. Further, the mean number of audit committee meetings was 4.70 , ranging from a minimum of two meetings to a maximum of 12 meetings per year. The audit committee members' education ranged from a minimum of $0 \%$ to a maximum of $100 \%$ of audit committee 


\section{Mll Macrothink}

International Journal of Accounting and Financial Reporting

ISSN 2162-3082

2020, Vol. 10, No. 2

members holding a degree in a financial discipline. On average, $41.80 \%$ of members held a financial degree.

\subsection{Correlation Matrix and Collinearity}

Table 2 shows the results of the variance inflation factor (VIF) and tolerance for the independent and control variables in the model. A tolerance (1/VIF) value of less than 0.20 and a VIF value of greater than 10 indicates the presence of collinearity. In addition, table 3 presents the correlation values of the variables for this study period. Overall, the correlations are far below the criteria of 0.8 suggested by Grewal, Cote and Baumgartner (2004) and Shearer and Clark (2016). Specifically, the results show negligible and low correlation among all variables. Given the low figures for collinearity, the VIF and tolerance results are within the acceptable range, which indicates the absence of multicollinearity.

Table 2. Results for VIF and tolerance

\begin{tabular}{lll}
\hline Variable & VIF & Tolerance (1/VIF) \\
\hline Board size (BS) & 1.61 & 0.620 \\
\hline Board independent directors (BIND) & 1.52 & 0.655 \\
\hline Board meetings (BM) & 1.30 & 0.769 \\
\hline Board members' education (BMED) & 1.13 & 0.885 \\
\hline Board members' experience (BMEX) & 1.28 & 0.783 \\
\hline Audit committee size (ACS) & 1.42 & 0.703 \\
\hline Audit committee independent members (ACIND) & 1.17 & 0.852 \\
\hline Audit committee meeting (ACM) & 1.53 & 0.652 \\
\hline Audit committee members' education (ACED) & 1.14 & 0.876 \\
\hline Firm age (FA) & 1.42 & 0.704 \\
\hline Feverage (LEV) & 1.07 & 0.932 \\
\hline
\end{tabular}


Table 3. Correlation matrix

\begin{tabular}{|c|c|c|c|c|c|c|c|c|c|c|c|c|c|c|c|}
\hline & & BS & BIND & BMI & BMED & BMEX & $\mathrm{ACS}$ & ACIND & $\mathrm{ACM}$ & ACED & ROA & ROE & FA & FS & LEV \\
\hline BS & Correlation & 1 & & & & & & & & & & & & & \\
\hline BIND & Correlation & 0.047 & 1 & & & & & & & & & & & & \\
\hline $\mathrm{BM}$ & Correlation & 0.075 & $0.200 * *$ & 1 & & & & & & & & & & & \\
\hline BMED & Correlation & -0.019 & 0.031 & 0.038 & 1 & & & & & & & & & & \\
\hline BMEX & Correlation & $0.358^{* *}$ & -0.071 & $0.116^{*}$ & $0.133^{* *}$ & 1 & & & & & & & & & \\
\hline $\mathrm{ACS}$ & Correlation & $0.479 * *$ & 0.003 & 0.074 & 0.044 & $0.151^{* *}$ & 1 & & & & & & & & \\
\hline ACIND & Correlation & 0.027 & $0.296^{* *}$ & -0.039 & 0.077 & 0.006 & -0.004 & 1 & & & & & & & \\
\hline $\mathrm{ACM}$ & Correlation & $0.294^{* *}$ & $0.181^{* *}$ & $0.407^{* *}$ & $0.143^{* *}$ & $0.208^{* *}$ & $0.199 * *$ & -0.070 & 1 & & & & & & \\
\hline ACED & Correlation & $-0.198^{* *}$ & -0.025 & $0.092^{*}$ & -0.035 & $0.105^{*}$ & $-0.156^{* *}$ & $0.146^{* *}$ & -0.058 & 1 & & & & & \\
\hline ROA & Correlation & $0.119^{*}$ & $0.197^{* *}$ & $0.119^{*}$ & 0.062 & 0.068 & 0.029 & $0.581^{* *}$ & $0.139 * *$ & $0.261^{* *}$ & 1 & & & & \\
\hline ROE & Correlation & $0.111^{*}$ & -0.057 & $0.292^{* *}$ & 0.042 & $0.104^{*}$ & -0.031 & 0.046 & $0.358^{* *}$ & $0.392^{* *}$ & $0.464^{* *}$ & 1 & & & \\
\hline FA & Correlation & -0.057 & $-0.383^{* *}$ & $-0.221^{* *}$ & -0.069 & 0.082 & $-0.161^{* *}$ & -0.059 & $-0.121^{* *}$ & -0.059 & 0.002 & 0.024 & 1 & & \\
\hline FS & Correlation & 0.072 & $-0.124^{* *}$ & $.166^{* *}$ & $0.168^{* *}$ & 0.068 & -0.044 & -0.075 & $0.314^{* *}$ & -0.004 & -0.080 & $0.105^{*}$ & $-0.202^{* *}$ & 1 & \\
\hline LEV & Correlation & 0.071 & 0.062 & 0.034 & $0.156^{* *}$ & 0.041 & 0.007 & -0.026 & 0.025 & -0.080 & -0.065 & 0.020 & -0.031 & -0.091 & 1 \\
\hline
\end{tabular}

** Correlation is significant at the 0.01 level (two-tailed).

* Correlation is significant at the 0.05 level (two-tailed).

\subsection{Overview of Results of Return on Assets}

Since this study uses panel data, some econometric issues need to be addressed. The Lagrange Multiplier (LM) test is employed to guide model selection. The result of the LM test is significant ( $\mathrm{p}$-value $<0.001$ ), thereby suggesting that panel regression is more suitable than OLS. In addition, since panel data models can be specified as either FE or RE, a Hausman test is employed. The Hausman test result is statistically insignificant $\left(\chi^{2}=11.38\right.$, p-value $=0.497$ ); consequently, a RE model is appropriate to use for ROA. The results of the two tests (Hausman and LM) are presented in Appendix 2. The results of the ROA model estimation are shown in Table 4.

Table 4. Random-effect panel data regression model for ROA

\begin{tabular}{lllll}
\hline & Variable & \multicolumn{2}{l}{ RE Model } & \\
\cline { 2 - 5 } & & Estimate & Std. Err & p-value \\
\hline $\begin{array}{l}\text { Independ } \\
\text { ent } \\
\text { variables }\end{array}$ & Board size (BS) & $0.082^{* *}$ & 0.315 & 0.015 \\
\cline { 2 - 5 } & Board independent directors (BIND) & $-0.002^{*}$ & 0.002 & 0.080 \\
\cline { 2 - 5 } & Board meetings (BM) & $0.090^{*}$ & 0.030 & 0.017 \\
\cline { 2 - 5 } & Board members' education (BMED) & 0.002 & 0.004 & 0.527 \\
\cline { 2 - 5 } & Board members' experience (BMEX) & -0.017 & 0.009 & 0.151 \\
\cline { 2 - 5 } & Audit committee size (ACS) & -0.035 & 0.101 & 0.736 \\
\cline { 2 - 5 } & $\begin{array}{l}\text { Audit committee independent members } \\
\text { (ACIND) }\end{array}$ & $0.036^{* * *}$ & 0.002 & $<0.001$ \\
\hline
\end{tabular}


Audit committee meetings (ACM)

$0.107^{* *}$

0.037

0.006

Audit committee members' education $0.008^{* * *} \quad 0.002<0.001$ (ACED)

\begin{tabular}{lllll}
\hline $\begin{array}{l}\text { Control } \\
\text { variables }\end{array}$ & Leverage (LEV) & -0.001 & 0.001 & 0.664 \\
\cline { 2 - 5 } & Firm age (FA) & 0.007 & 0.007 & 0.239 \\
\cline { 2 - 5 } & Firm size (FS) & -0.129 & 0.129 & 0.168 \\
\hline & Constant & 0.941 & 0.693 & 0.142 \\
\hline
\end{tabular}

Model fit: Wald $($ chi-square $)=248.11$, p-value $<0.001$

R-squared $=0.430$

Note: $* * *, * * *$ indicate statistical significance at the $10 \%, 5 \%$ and $1 \%$ levels, respectively.

The proposed RE model for ROA, is statistically significant $\left(\chi^{2}=248.11\right.$, p-value $\left.<0.001\right)$ and able to fit the linear relationship between ROA and the selected independent variables, with a $\mathrm{R}^{2}$ of $43.0 \%$. As shown in table 4 board size, board meetings, audit committee independent members, audit committee meetings and audit committee members' education have significant positive relationships with ROA, while the only variable with a negative relationship is board independent directors. The other variables, members' education, board members' experience, and audit committee size did not produce a significant relationship to ROA.

\subsection{Overview of Results of Return on Equity}

For the ROE model, the LM test suggested the panel regression methods $\left(\chi^{2}=36.58\right.$, p-value $<0.001)$. The Hausman test indicated that the RE is the appropriate approach for the ROE model $\left(\chi^{2}=10.65, p\right.$-value $\left.=0.559\right)$. The results of the Hausman tests are given in Appendix 2. The results of the ROE model estimation are given in Table 5.

Table 5. Random-Effect panel data regression model for ROE

\begin{tabular}{lllll}
\hline & Variable & \multicolumn{2}{l}{ RE Model } & \\
\cline { 2 - 5 } & & Estimate & Std. Err & p-value \\
\hline $\begin{array}{l}\text { Independe } \\
\text { nt } \\
\text { variables }\end{array}$ & Board size (BS) & $0.141^{* *}$ & 0.052 & 0.007 \\
\cline { 2 - 5 } & Board independent directors (BIND) & $-0.014^{* *}$ & 0.005 & 0.010 \\
\cline { 2 - 5 } & Board meetings (BM) & $0.211^{* * *}$ & 0.056 & $<0.001$ \\
\cline { 2 - 5 } & Board members' education (BMED) & 0.004 & 0.005 & 0.432 \\
\cline { 2 - 5 } & Board members' experience (BMEX) & -0.004 & 0.019 & 0.776 \\
\hline
\end{tabular}


$\begin{array}{llll}\text { Audit committee size (ACS) } & -0.380^{* * *} & 0.158 & 0.016\end{array}$

$\begin{array}{llll}\text { Audit committee independent members } & 0.002 & 0.004 & 0.532\end{array}$ (ACIND)

\begin{tabular}{llll} 
Audit committee meetings (ACM) & $0.366^{* * *}$ & 0.058 & $<0.001$ \\
\hline $\begin{array}{l}\text { Audit committee members' education } \\
\text { (ACED) }\end{array}$ & $0.025^{* * *}$ & 0.003 & $<0.001$ \\
\hline
\end{tabular}

\begin{tabular}{lllll}
\hline $\begin{array}{l}\text { Control } \\
\text { variables }\end{array}$ & Leverage (LEV) & 0.002 & 0.003 & 0.451 \\
\cline { 2 - 5 } & Firm age (FA) & 0.009 & 0.009 & 0.347 \\
\cline { 2 - 5 } & Firm size (FS) & -0.105 & 0.151 & 0.489 \\
\hline & Constant & 0.655 & 0.979 & 0.503
\end{tabular}

Model fit: Wald (chi-square) $=180.32$, p-value $<0.001$

R-squared $=0.352$

Note: $* * *, * * *$ indicate statistical significance at the $10 \%, 5 \%$ and $1 \%$ levels, respectively.

As shown in the table the estimated equation is statistically significant (p-value $<0.001$ ). The $\mathrm{R}^{2}$ indicates that the predictors explain $35.2 \%$ of variation in ROE. The results demonstrate that board size and board meetings have significant positive relationships with ROE. In addition, audit committee meetings and audit committee members' education have significant positive relationships with ROE. Meanwhile, significant negative relationships are identified between ROE and board composition and audit committee size. The other variables, board members' education and audit committee composition did not produce a significant relationship to ROE. The results of the ROA and ROE model are discussed in the next sub-section.

\subsection{Discussion of Results}

From an overall perspective, five board characteristics had the same effect on ROA and ROE. With respect to the four audit committee characteristics, two variables (audit committee meetings and audit committee members' education) were significant, while, for the other two variables, audit committee size was significant for ROE, while audit committee independent members was significant for ROA. The two differences in significance between ROA and ROE for audit committee characteristics is unsurprising because, as indicated by Rappaport (1986); Finegan (1991); and Koller Goedhart and Wessels (1996), the two financial performance measures have different focuses.

The findings as given in Table 6 indicate that large board sizes do contribute to firm financial performance. This can be explained by the communication and coordination among firm directors on the board in the UAE, which increase their ability to monitor and evaluate executive managers. In addition, the findings of ROA and ROE support the argument that 
companies may include independent directors on the board for legitimacy purposes, rather than for improvement of firm financial performance (DiMaggio and Powell, 2004). In other words, a possible reason for the negative effect on ROA and ROE for UAE listed firms could be because the increase in proportion of independent board members occurred to strictly comply with the law. Another possible reason could be the insufficient knowledge held by independent directors, which did not translate to increased firm financial performance. Furthermore, the role of independent directors in UAE listed firms is still open to debate because of a lack of clarification regarding the specific role of independent directors (Altamimi and Charif, 2012).

Table 6. Summary result of regression model for ROA \& ROE

\begin{tabular}{lll}
\hline Variable & Result & \\
\cline { 2 - 3 } & ROA & ROE \\
\hline Board size (BS) & Pos, Sig & Pos, Sig \\
\hline Board independent directors (BIND) & Neg, Sig & Neg, Sig \\
\hline Board meetings (BM) & Pos, Sig & Pos, Sig \\
\hline Board members' education (BMED) & Pos, Insig & Pos, Insig \\
\hline Board members' experience (BMEX) & Neg, Insig & Neg, Insig \\
\hline Audit committee size (ACS) & Neg, Insig & Neg, Sig \\
\hline Audit committee independent members (ACIND) & Pos, Sig & Pos, Insig \\
\hline Audit committee meetings (ACM) & Pos, Sig & Pos, Sig \\
\hline Audit committee members' education (ACED) & Pos, Sig & Pos, Sig \\
\hline
\end{tabular}

The results indicated that board meetings had a significant and positive effect on ROA and ROE, which suggests that more board meetings led to higher financial performance of the UAE listed companies. This finding is supported by previous studies by Ntim and Oseit (2011) and Tarak, Nath and Apu (2013).

From an accounting-based perspective, it seems that board members holding educational qualifications from developed-country universities is a positive but not significant factor for the financial performance of UAE listed firms. This view is supported by Darmadi (2013) in Indonesia, and by Vo and Phan (2013) study in Vietnam.

With respect to the non-significant outcome for board members' experience, a possible reason for this result is that the UAE CG codes did not state the level of experience that the members should hold. Although very little empirical research has been undertaken in this area, this view is supported by Johl (2006). Thus, boards need to ensure they have a suitable 
mix of members with appropriate skills and experience to cope with business complexities, competition and change.

In terms of audit committee size, relationship was significant and negative for ROE and non-significant for ROA. One possible reason for the significant result for ROE could be the lack of a specific description and specification of the number of audit committee members in the UAE CG code, which only recommended having at least three members on the committee. Thus, it could be due to a lack of communication and coordination among firm audit committee members in the UAE.

The present research found that audit committee independent members had a significant and positive effect on the ROA and an insignificant and positive relationship with ROE. One possible reason for the non-significant effect of audit committee composition on ROE is that the ROE indicator measured the effectiveness of UAE firms taking advantage of their equity base. That is, it indicated how effectively a company used its shareholders' money (Almatari, Alswidi and Fadzil, 2014c). Thus, it would seem that audit committee members of UAE listed firms are less effective in taking advantage of their earnings advantage from their equity base, as opposed to taking earnings advantage of their base of assets.

A significant and positive relationship between audit committee meetings and ROA and ROE was identified. The finding is supported by prior studies, such as those by Hsu (2010) and Almatari, Alswidi and Fadzil (2014b).

The present research found that audit committee members' education had a significant and positive effect on both ROA and ROE. This result is supported by previous studies such as Yang and Krishnan (2005), Aldamen et al. (2012) and Almatari, Alswidi and Fadzil (2014a). The result supports changes to the CG code, which stated, in regard to members' education, that the audit committee should have at least one member with a financial qualification or an expert in accounting and financial affairs.

\section{Conclusion}

This study investigated the association between board and audit committee characteristics and the financial performance of UAE listed firms as measured by ROA and ROE. Panel regression models were used to test the study's nine hypotheses based on a study sample of 47 listed UAE companies on the DFM and ADX covering a period of 10 years from 2006 to 2015. Our results suggest that board size, board meetings, audit committee meetings and audit committee members' experience all had a significant and positive impact on firm financial performance as measured by ROA and ROE. In addition, audit committee independent members had a positive and significant impact as measured by ROA. Conversely, board independent directors had a significant and negative impact of firm financial performance as measured by ROA and ROE while audit committee size was found to have a significant and negative impact as measured by ROE only. The remaining two variables, board members' education and board members' experience were found to be insignificant. Overall our results demonstrate that board and audit characteristics do have an important influence on impact of firm financial performance. 


\section{Mll Macrothink}

International Journal of Accounting and Financial Reporting

ISSN 2162-3082

2020, Vol. 10, No. 2

Some implications arising from the results suggest that there is a lack of an appropriate skill base among members of the board of directors. Thus, UAE firms should consider appointing directors with a more diverse skill set to enhance board effectiveness. The analysis suggests the need to rationalise the size of audit committees, which were found to exert a significant and negative influence on firm financial performance. The UAE CG code does not mention a specific number of members to constitute an effective audit committee size, and does not contain any specific guideline about the number of audit committee members. This is an issue that could be investigated and supported with more specific recommendations. The overall findings suggest that too many independent directors negatively impact financial performance. Currently, the UAE codes endorse a regulation requiring that listed firms appoint a minimum one-third of board directors as independent directors. Hence, the UAE should specify the maximum proportion of independent members on the board to ensure that firms do not have $100 \%$ of independent directors on the board, given that a well-diversified board can improve firm financial performance. Future policy should focus more on the relationship between audit committee members' education and firm financial performance. Specifically, that UAE listed firms should consider introducing a requirement whereby all audit committee members must have a recognised qualification in finance or significant expertise in accounting and financial affairs.

There are limitations inherent in this study that may affect the generalisability of our results. First, was the exclusion of non-listed companies in the UAE from the sample due to the UAE government decision to introduce the CG codes only for listed companies in the ADX and DFM. Second, the amount of available data to assess UAE CG practice for listed companies restricted the sample size to approximately $37 \%$ of the population. Third, the focus on secondary data meant that other potential factors that influence firm financial performance were omitted such as the views from a wide range of stakeholders-such as regulators, investors, foreign corporate partners or consumers. Fourth, this research used ROA and ROE to measure firm financial performance because these are traditional and common measurements however other measures of firm financial performance, such as Tobin's Q, profit margin, earnings per share and return on sales could also have been used. Consequently, the results should be interpreted with caution.

Future research could be carried out on a comparative study of UAE with other Middle Eastern countries and/or developing countries. Further studies could expand the notion of CG beyond board and audit committee characteristics by exploring effects of various other committees, such as remuneration and nomination committees. Another avenue could be an investigation of the difference between listed and non-listed companies in terms of CG practices in the UAE.

\section{References}

Aldamen, H., Duncan, K., Kelly, S., McNamara, R., \& Nagel, S. (2012). Audit committee characteristics and firm performance during the global financial crisis. Accounting and Finance, 52(4), 971-1000. 


\section{MInstitute Macrothink $^{\text {Int }}$}

International Journal of Accounting and Financial Reporting

ISSN 2162-3082 2020, Vol. 10, No. 2

Almatari, E., Alswidi, A., \& Fadzil, F. (2013). The effect of the internal audit and firm performance: A proposed research framework. International Review of Management and Marketing, 4(1), 34-41.

Almatari, E., Alswidi, A., \& Fadzil, F. (2014a). The effect on the relationship between board of directors characteristics on firm performance in Oman: Empirical study. Middle-East Journal of Scientific Research, 21(3), 556-574.

Almatari, E., Alswidi, A., \& Fadzil, F. (2014b). The effect of board of directors characteristics, audit committee characteristics and executive committee characteristics on firm performance in Oman: An empirical study. Asian Social Science, 10(11), 149-171.

Almatari, E., Alswidi, A., \& Fadzil, F. (2014c). The measurements of firm performance's dimensions. Asian Journal of Finance and Accounting, 6(1), 24-49.

Alqatamin, R. M. (2018). Audit committee effectiveness and company performance: Evidence from Jordan. Accounting and Finance Research, 7(2), 48-60.

Altamimi, H. A., \& Charif, H. (2012). Corporate governance practices and the role of the board of directors: Evidence from UAE conventional and Islamic banks. Corporate Ownership and Control, 10(4), 207-213.

Ananchotikul, S. B. (2007). Essays on corporate governance in emerging markets. Doctoral thesis, University of California, Berkeley, ProQuest.

Andrew, H. (2015). UAE says no to corruption. Retrieved 12 September 2016, from https://www.lexology.com/library/detail.aspx?g=9764a038-309a-45ee-9411-e59aa78e3fae

Baddeley, M., \& Barrowclough, D. V. (2009) Running regressions: A practical guide to quantitative research in economics, finance and development studies. Cambridge University Press, New York.

Badolato, P., Donelson, D., \& Ege, M. (2014). Audit committee financial expertise and earnings management: The role of status. Journal of Accounting and Economics, 58(2-3), 208-230.

Boone, A. L., Casares Field, L., Karpoff, J. M., \& Raheja, C. G. (2007). The determinants of corporate board size and composition: An empirical analysis. Journal of Financial Economics, 85(1), 66-101.

Dabor, A. O., Isiavwe, D. T., Ajagbe, M. A., \& Oke, A. O. (2015). Impact of corporate governance on firms' performance. International Journal of Economics, Commerce and Management, 3(6), 634-653.

Dalton, D. R., Daily, C. M., Ellstrand, A. E., \& Johnson, J. L. (1998). Meta-analytic reviews of board composition, leadership structure, and financial performance. Strategic Management Journal, 19(3), 269-290.

Darmadi, S. (2013). Board members' education and firm performance: Evidence from a developing economy. International Journal of Commerce and Management, 23(2), 113-135. 


\section{Mll Macrothink}

International Journal of Accounting and Financial Reporting

ISSN 2162-3082 2020, Vol. 10, No. 2

DiMaggio, P. J., \& Powell, W. W. (2004). The iron cage revisited: Institutional isomorphism and collective rationality in organizational fields, The New Economic Sociology. Princeton University Press, Princeton, New Jersey.

Elghuweel, M. I. (2015). Empirical essays on corporate governance and corporate decisions in emerging economies: The case of Oman. University of Glasgow, Glasgow.

Emirates Securities and Commodities Authority (ESCA). (2016). The Chairman of Authority's Board of Directors' Resolution No. (7) of 2016 Concerning the Standards of Institutional Discipline and Governance of Public Shareholding Companies. United Arab Emirates.

Finegan, P. T. (1991). Maximizing shareholder value at the private company. Journal of Applied Corporate Finance, 4(1), 30-45.

Ghabayen, M. A. (2012). Board characteristics and firm performance: Case of Saudi Arabia. International Journal of Accounting and Financial Reporting, 2(2), 168-200.

Gottesman, A. A., \& Morey, M. R. (2006). Does a better education make for better managers? An empirical examination of CEO educational quality and firm performance. Pace University Press, New York.

Grewal, R., Cote, J. A., \& Baumgartner, H. (2004). Multicollinearity and measurement error in structural equation models: Implications for theory testing. Marketing Science, 23(4), 519-529.

Hair, J., Black, W., Babin, B., \& Anderson, R. (2010) Multivariate data analysis (7th ed.). Upper Saddle River, Pearson Education International, New Jersey.

Hamdan, A. M., Sarea, A. M., \& Reyad, S. M. R. (2013). The impact of audit committee characteristics on the performance: Evidence from Jordan. International Management Review, 9(1), 32-41.

Hamid, A., \& Aziz, R. (2012). Impact of the amendments of Malaysian code of corporate governance (2007) on governance of GLCS and performance. World Academy of Science, Engineering and Technology, International Journal of Social, Behavioral, Educational, Economic, Business and Industrial Engineering, 6(11), 3181-3186.

Hsu, H.-E. (2010). The relationship between board characteristics and financial performance: an empirical study of United States initial public offerings. International Journal of Management, 27(2), 332-341.

Hsu, W., \& Petchsakulwong, P. (2010). The impact of corporate governance on the efficiency performance of the Thai non-life insurance Industry. The Geneva Papers on Risk and Insurance-Issues and Practice, 25(1), 28-49.

Ibrahim, D. N., Raman, K. J., \& Saidin, F. B. S. (2009). Audit committee characteristics and quality of unaudited financial accounts. Singapore Management Review, 31(2), 19-33. 


\section{MInstitute ${ }^{\text {Mink }}$}

International Journal of Accounting and Financial Reporting

ISSN 2162-3082

Jensen, M. C. (1993). The modern industrial revolution, exit, and the failure of internal control systems. Journal of Finance, 48(3), 831-880.

Johl, S. K. (2006). Corporate entrepreneurship and corporate governance: An empirical analysis. Doctoral thesis, University of Nottingham, Nottingham.

Johl, S. K., Kaur, S., \& Cooper, B. J. (2015). Board characteristics and firm performance: evidence from Malaysian public listed firms. Journal of Economics, Business and Management, 3(2), 339-343.

Kajola, S. O. (2008). Corporate governance and firm performance: The case of Nigerian listed firms. European Journal of Economics, Finance and Administrative Sciences, 14(14), $16-28$.

Khalifa, A. M. G. (2018). The effect of board and audit committee characteristics on the financial performance of United Arab Emirates firms. Unpublished thesis, Victoria University, Melbourne.

Khan, A., \& Awan, S. H. (2012). Effect of board composition on firm's performance: a case of Pakistani listed companies. Interdisciplinary Journal of Contemporary Research in Business, 3(10), 853-863.

Khatab, H., Masood, M., Zaman, K., Saleem, S., \& Saeed, B. (2011). Corporate governance and firm performance: A case study of Karachi stock market. International Journal of Trade, Economics and Finance, 2(1), 39-43.

Koller, T., Goedhart, M., \& Wessels, D, (1996). Valuation: Measuring and managing the value of companies. John Wiley and Sons, New Jersey.

Kyereboah-Coleman, A. (2008). Corporate governance and firm performance in Africa: A dynamic panel data analysis. Studies in Economics and Econometrics, 32(2), 1-24.

Kyereboah-Coleman, A., \& Biekpe, N. (2006). The link between corporate governance and performance of the non-traditional export sector: Evidence from Ghana. Corporate Governance: The International Journal of Business in Society, 6(5), 609-623.

Lipton, M., \& Lorsch, J. W. (1992). A modest proposal for improved corporate governance. Business Lawyer, 48(1), 59-77.

Mura, R. (2007). Firm performance: Do non-executive directors have minds of their own? Evidence from UK panel data. Financial Management, 36(3), 81-112.

Ntim, C. G., \& Oseit, K. A. (2011). The impact of corporate board meetings on corporate performance in South Africa. African Review of Economics and Finance, 2(2), 83-103.

O'Connell, V., \& Cramer, N. (2010). The relationship between firm performance and board characteristics in Ireland. European Management Journal, 28(5), 387-399.

OECD. (2015). OECD principles of corporate governance. OECD Publishing, Paris. 


\section{MInstitute Macrothink $_{\text {Int }}$}

International Journal of Accounting and Financial Reporting ISSN 2162-3082

Organisation for Economic Co-operation and Development (OECD). (n.d.) Organisation of economic cooperation and development principles of corporate governance. OECD Publishing, Paris.

Pfeffer, J., \& Salancik, G. R. (2003). The external control of organizations: A resource dependence perspective (1st ed.). Stanford University Press, Harper and Row, New York.

Rappaport, A. (1986). Creating shareholder value: The new standard for business performance (1st ed.). Simon and Schuster, New York Free Press, New York.

Rouf, M. (2011). The relationship between corporate governance and value of the firm in developing countries: Evidence from Bangladesh. The International Journal of Applied Economics and Finance, 5(3), 237-244.

Shearer, R., \& Clark, T. (2016). Are we drawing the correct conclusions? Regression analysis in the nonprofit literature. Canadian Journal of Nonprofit and Social Economy Research, $7(1), 22-28$.

Steven, B., \& Carla, S. (2010). United Arab Emirates: Changes in Corporate Governance Legislation Ministerial Resolution No. 518 of 2009. Retrieved 25 May 2016, from http://www.mondaq.com/x/96232/corporate+governance/changes+in+corporate+go\%20verna nce+legislation+ministerial+resolution + no $+518+$ of +2009

Tarak Nath, S., \& Apu, M. (2013). Impact of board composition and board meeting on firms' performance: a study of selected Indian companies. Vilakshan: The Ximb Journal of Management, 10(2), 99-112.

Trading Economics. (2017). Trading, economics-UAE GDP. Retrieved 19 August 2017, from http://www.tradingeconomics.com/united-arab-emirates/gdp

Vo, D., \& Phan, T. (2013). Corporate governance and firm performance: Empirical evidence from Vietnam. Journal of Economic Development, 6(2), 62-78.

Yang, J. S., \& Krishnan, J. (2005). Audit committees and quarterly earnings management. International Journal of Auditing, 9(3), 201-219.

Yasser, Q. R., Entebang, H. A., \& Mansor, S. A. (2011). Corporate governance and firm performance in Pakistan: the case of Karachi Stock Exchange (KSE)-30. Journal of Economics and International Finance, 3(8), 482-491.

Zhu, D. H., \& Shen, W. (2016). Why do some outside successions fare better than others? The role of outside CEOs' prior experience with board diversity. Strategic Management Journal, 37(13), 1-28. 


\section{Appendix}

Appendix 1. Study variables and their measures

\begin{tabular}{|c|c|c|c|c|}
\hline No & & Variables & Measures & Sources \\
\hline \multirow[t]{5}{*}{1} & \multirow{5}{*}{$\begin{array}{l}\text { Board } \\
\text { characteristics } \\
\text { (BC) }\end{array}$} & Board size (BS) & The number of members in the board & DFM, ADX, ESCA and firm annual and CG reports \\
\hline & & $\begin{array}{l}\text { Board independent directors } \\
\text { (BIND) }\end{array}$ & $\begin{array}{l}\text { The ratio of independent members to total members in the } \\
\text { board }\end{array}$ & DFM, ADX, ESCA and firm annual and CG reports \\
\hline & & Board meetings (BM) & The number of board meetings held per year & $D F M, A D X, E S C A$ and firm annual and $C G$ reports \\
\hline & & $\begin{array}{l}\text { Board members' education } \\
\text { (BMED) }\end{array}$ & $\begin{array}{l}\text { The ratio of directors who hold a degree from developed- } \\
\text { country universities to total members in the board }\end{array}$ & DFM, ADX, ESCA and firm annual and CG reports \\
\hline & & $\begin{array}{l}\text { Board members' experience } \\
\text { (BMEX) }\end{array}$ & $\begin{array}{l}\text { The average number of years of experience of board } \\
\text { members }\end{array}$ & DFM, ADX, ESCA and firm annual and CG reports \\
\hline \multirow[t]{4}{*}{2} & \multirow{4}{*}{$\begin{array}{l}\text { Audit } \\
\text { committee } \\
\text { characteristics } \\
\text { (ACC) }\end{array}$} & Audit committee size (ACS) & The number of members in the committee & DFM, ADX, ESCA and firm annual and CG reports \\
\hline & & $\begin{array}{l}\text { Audit committee independent } \\
\text { members (ACIND) }\end{array}$ & $\begin{array}{l}\text { The ratio of independent members to total members in the } \\
\text { committee }\end{array}$ & DFM, ADX, ESCA and firm annual and CG reports \\
\hline & & Audit committee meetings (ACM) & The number of committee meetings held per year & DFM, ADX, ESCA and firm annual and CG reports \\
\hline & & $\begin{array}{l}\text { Audit committee members' } \\
\text { education (ACED) }\end{array}$ & $\begin{array}{l}\text { The ratio of number of audit committee members holding a } \\
\text { degree in a financial discipline to total committee members }\end{array}$ & DFM, ADX, ESCA and firm annual and CG reports \\
\hline \multirow[t]{2}{*}{3} & \multirow[t]{2}{*}{$\begin{array}{l}\text { Financial } \\
\text { performance }\end{array}$} & Return on Assets (ROA) & (Net income) $\div$ (average total assets) & $\begin{array}{l}\text { DFM, ADX, firm annual reports and Orbis-Bureau } \\
\text { van Dijk and Datastream databases }\end{array}$ \\
\hline & & Return on Equity (ROE) & (Net income) $\div$ (shareholder's equity) & $\begin{array}{l}\text { DFM, ADX, firm annual reports and Orbis-Bureau } \\
\text { van Dijk and Datastream databases }\end{array}$ \\
\hline \multirow[t]{3}{*}{4} & \multirow{3}{*}{$\begin{array}{l}\text { Control } \\
\text { variables }\end{array}$} & Firm age (FA) & The number of years since establishment & Firm annual reports, DFM and ADX \\
\hline & & Leverage (LEV) & (Total debt $) \div($ shareholders' equity $)$ & $\begin{array}{l}\text { Firm annual reports and Orbis-Bureau van Dijk and } \\
\text { Datastream databases }\end{array}$ \\
\hline & & Firm size (FS) & The natural logarithm of total assets & Firm annual reports and Orbis-Bureau van Dijk \\
\hline
\end{tabular}

Appendix 2. Hausman and Lagrange multiplier tests for ROA and ROE models

\begin{tabular}{ll}
\hline Hausman test $[$ ROA] & \\
\hline Chi-square & p-value \\
\hline 11.38 & 0.4970 \\
\hline
\end{tabular}

\section{Breusch and Pagan Lagrangian multiplier test for RE results}

\begin{tabular}{ll}
\hline Chi-square & p-value \\
\hline 12.89 & $<0.001$ \\
\hline
\end{tabular}

\section{Hausman test [ROE]}

\begin{tabular}{ll}
\hline Chi-square & p-value \\
\hline 10.65 & 0.5594 \\
\hline
\end{tabular}

\section{Breusch and Pagan Lagrangian multiplier test for $\mathrm{RE}$ results}

Chi-square p-value

$36.58<0.001$

\section{Copyright Disclaimer}

Copyright for this article is retained by the author(s), with first publication rights granted to the journal.

This is an open-access article distributed under the terms and conditions of the Creative Commons Attribution license (http://creativecommons.org/licenses/by/4.0/) 